\title{
Glycerol Teichoic Acid as an Antigenic Determinant in a Gram-negative Bacterium Butyrivibrio fibrisolvens
}

\author{
By M. ELISABETH SHARPE, J. H. BROCK* AND B. A. PHILLIPS \\ National Institute for Research in Dairying, Shinfield, Reading RG2 $9 A T$ \\ (Received Io January 1975)
}

\begin{abstract}
SUMMARY
An antigenic determinant isolated from a strain of the Gram-negative bacterium Butyrivibrio fibrisolvens reacted with specific antisera to the polyglycerophosphate backbone of membrane teichoic acids of lactobacilli. It gave a reaction of identity with membrane glycerol lipoteichoic acid and glycerol teichoic acid preparations from lactobacilli, and with phenol extracts of other Gram-positive bacteria. The antigen-antibody reaction was strongly inhibited by glycerolphosphoryl-glycerol-phosphoryl-glycerol and the chemical composition was consistent with glycerol teichoic acid. It was concluded that this Gram-negative bacterium contained a glycerol teichoic acid whose polyglycerophosphate backbone was acting as antigenic determinant. Extracts of 33 out of 52 other strains of butyrivibrios examined gave similar reactions.
\end{abstract}

\section{INTRODUCTION}

Membrane glycerol teichoic acids occur in most Gram-positive bacteria (Baddiley, 1970). Their polyglycerophosphate backbone may act as a common antigenic determinant, and allow their presence to be detected serologically (Sharpe et al. 1973). There have not been any fully authenticated reports of teichoic acids in Gram-negative bacteria. During an attempt to detect serologically the presence of the polyglycerophosphate backbone of membrane glycerol teichoic acid in Gram-variable anaerobic cocci, a strain of the Gram-negative anaerobe Butyrivibrio fibrisolvens Nor 37 was also examined. A phenol extract of this bacterium gave an unexpected strong positive precipitin reaction against the antiserum to polyglycerophosphate determinant, indicating the possible presence of a glycerol teichoic acid as an antigenic factor. This organism was therefore further investigated and other strains of butyrivibrios were also examined serologically for the presence of glycerol teichoic acid antigenic determinant.

\section{METHODS}

Strains of bacteria examined. Most of the 19 laboratory strains of butyrivibrios examined (Table I) have been described previously (Bryant \& Small, I956; Shane, Gouws \& Kistner, I969; van Gylswyk \& Roché, 1970; Sharpe \& Reiter, I972; Leatherwood \& Sharma, I972; Roché et al. 1973). Shane et al. (1969) divided butyrivibrios into two groups: group I which utilized acetate and produced large amounts of lactate, and group 2 which produced acetate but little lactate. The two groups also had different nutritional requirements. Of the laboratory strains, CE65, CE66, 6B, 6D, 7A and I I belonged to group 2, strain CE74 was a borderline strain eventually assigned to group I by nutritional requirements, whilst the other I 2 strains all belonged to group I. Strain JL originally grew atypically as long twisted chains forming a

* Present address: Fundacion F. Cuenca Villoro, Gasconde Gotor 4, Zaragoza, Spain. 
Table I. Strains of butyrivibrios examined

\begin{tabular}{|c|c|c|c|c|}
\hline Species & $\begin{array}{l}\text { No. of } \\
\text { strains }\end{array}$ & Strains & Source & Received from \\
\hline \multirow[t]{4}{*}{$\begin{array}{l}\text { Butyrivibrio } \\
\text { fibrisolvens }\end{array}$} & 4 & $\begin{array}{l}\text { DI }(\text { ATCCI } 2560) \\
49, \text { A } 38, \text { CI } 4\end{array}$ & Bovine rumen & M. P. Bryant \\
\hline & 2 & Nor 37 , IL6-3I & Bovine rumen & NIRD \\
\hline & 4 & $7,12,15,17$ & Ovine rumen & N. O. van Gylswyk \\
\hline & I & 834 & Ovine rumen & P. N. Hobson \\
\hline \multirow[t]{4}{*}{ Butyrivibrio spp. } & 7 & $\begin{array}{l}\mathrm{CE} 65, \mathrm{CE} 66, \mathrm{CE} 74, \\
\text { 6B, 6D, 7A, I I }\end{array}$ & Ovine rumen & N. O. van Gylswyk \\
\hline & I & $\mathrm{JL}$ & Bovine rumen & J. M. Leatherwood \\
\hline & $3 \mathrm{I}$ & Fresh isolates & Bovine rumen & NIRD \\
\hline & 2 & Fresh isolates & Bovine caecum & NIRD \\
\hline
\end{tabular}

ATCC, American Type Culture Collection;

NIRD, isolated at the National Institute for Research in Dairying.

double helix (Leatherwood \& Sharma, 1972) but on our media reverted to morphology typical of butyrivibrios. Strains Nor 37 and IL6-3 I have now been identified as $B$. fibrisolvens (Bryant \& Small, 1956).

Cultivation. Butyrivibrios were cultured anaerobically using the Hungate (I950) technique and the medium Mio described by Sharpe, Latham \& Reiter (I969). Other bacteria were cultured in appropriate conventional media.

Preparation of extracts. (i) Phenol extracts. Bacteria were grown in $100 \mathrm{ml}$ broth, harvested by centrifugation, and $0.4 \mathrm{~g}$ wet wt bacteria was taken up in $2 \mathrm{ml}$ distilled water, extracted twice with an equal volume of $90 \%$ phenol at $68{ }^{\circ} \mathrm{C}$ for $15 \mathrm{~min}$, and the aqueous phase dialysed (Wicken, Gibbens \& Knox, 1973). (ii) Autoclaved extracts. Butyrivibrios centrifuged from $10 \mathrm{ml}$ medium MIo broth were suspended in $0.2 \mathrm{ml}$ of $0.02 \mathrm{M}$-phosphate$0.15 \mathrm{M}-\mathrm{NaCl}$ at $\mathrm{pH} 7.2$ (PBS), autoclaved for $10 \mathrm{~min}$ at $10 \mathrm{lb} / \mathrm{in}^{2}$ and the debris removed by centrifugation.

Preparation of glycerol teichoic acid from B. fibrisolvens Nor 37. During this preparation samples were monitored serologically by ring precipitin test, with an antiserum to the membrane glycerol teichoic acid antigenic determinant found in Gram-positive bacteria (Sharpe et al. 1973). Strain Nor 37 (50 g wet wt) was grown under anaerobic conditions in I5 1 medium Mio broth, harvested by centrifugation, washed in PBS and disrupted in a Braun homogenizer (Shandon) for $3 \mathrm{~min}$. Whole bacteria were separated at $2000 \mathrm{~g}$ for $4 \mathrm{~min}$ and the soluble fraction separated from the walls by centrifugation at $17000 \mathrm{~g}$ for $30 \mathrm{~min}$. The walls were washed three times with distilled water which removed all serologically-active material, and the washings and soluble fraction were pooled, dialysed against four daily changes of distilled water, and then reduced from approximately $600 \mathrm{ml}$ to $100 \mathrm{ml}$ by rotary evaporation. Molar $\mathrm{KH}_{2} \mathrm{PO}_{4}(8 \mathrm{ml})$ was added, the $\mathrm{pH}$ adjusted to $5 \cdot 0$, and the solution incubated overnight at $37^{\circ} \mathrm{C}$ with $5 \mathrm{mg}$ DNAase (Koch-Light) and Io mg RNAase (Koch-Light). A precipitate formed, and was sedimented by centrifugation at $40000 \mathrm{~g}$ for $30 \mathrm{~min}$. This precipitate was then extracted with five successive $40 \mathrm{ml}$ portions of phosphate-buffered saline $(0.15 \mathrm{M}-\mathrm{NaCl}+0.03 \mathrm{M}$-phosphate, $\mathrm{pH} 7.0)$. Each extraction was performed for $\mathrm{I} 8 \mathrm{~h}$ at $37^{\circ} \mathrm{C}$, merthiolate $(0.01 \%)$ being added to prevent bacterial growth. These extracts had titres of 64 , $32,16,4$ and 2 respectively, and were combined with the supernatant from the $40000 \mathrm{~g}$ centrifugation which had a titre of 64 . After dialysing four times against distilled water the solution was concentrated to $17 \mathrm{ml}$ and then dialysed overnight against $0.02 \mathrm{M}$-phosphate $\mathrm{pH} 6 \cdot 85$. 
The material was then chromatographed on DEAE cellulose and Sepharose $4 \mathrm{~B}$, as described by Sharpe et al. (1973), except that a second passage of the serologically-active material through DEAE cellulose was included before Sepharose $4 \mathrm{~B}$ chromatography. The yield of material from the Sepharose $4 \mathrm{~B}$ column was $22 \mathrm{mg}$, but as this still contained some protein, $18 \mathrm{mg}$ was treated with trichloroacetic acid (TCA) and ethanol (Sharpe et al. I973). The final yield of material was only $\mathrm{I} \cdot 9 \mathrm{mg}$.

Membrane glycerol teichoic acid preparations. Membrane teichoic acid from Lactobacillus casei R094 (NCDOI5I) was prepared as described by Sharpe et al. (1973). Membrane lipoteichoic acid from L. fermentum NCTC699I (Wicken et al. 1973) was kindly provided by Dr K. W. Knox, Institute of Dental Research, United Dental Hospital, Sydney, Australia.

Inhibitor of precipitin test. Glycerol-phosphoryl-glycerol-phosphoryl-glycerol $\left(\mathrm{G}_{3} \mathrm{P}_{2}\right)$ was prepared from cardiolipin (General Biochemicals, Chagrin Falls, Ohio, U.S.A.) by mild deacylation (Wilkinson, I968).

Extraction of Nor 37 walls. Washed walls, obtained during the preparation of the glycerol teichoic acid, were extracted with phenol as described for extraction of whole bacteria, or with $10 \%(\mathrm{v} / \mathrm{v})$ TCA overnight at $4{ }^{\circ} \mathrm{C}$.

Chemical analysis of glycerol teichoic acid from Nor 37. Estimations of total phosphorus, hexose and ester-linked amino acid, and methods for acid hydrolysis and paper chromatography were as described by Sharpe et al. (1973). Alkaline hydrolysis was carried out with $2 \mathrm{M}-\mathrm{NaOH}$ for $2 \mathrm{~h}$ at $100{ }^{\circ} \mathrm{C}$ in a sealed tube, and the hydrolysate passed through a column of Dowex 50 resin $\left(\mathrm{NH}_{4}{ }^{+}\right.$form) before evaporating to dryness.

Glycerol was estimated by the following procedure: the sample $(400 \mu \mathrm{g})$ was hydrolysed with $4 \mathrm{ml}$ of $2 \mathrm{M}-\mathrm{HCl}$ for $2 \mathrm{~h}$ at $100{ }^{\circ} \mathrm{C}$ in a stoppered tube. The acid was neutralized by cautious addition of solid $\left(\mathrm{NH}_{4}\right)_{2} \mathrm{CO}_{3}$ and the $\mathrm{pH}$ adjusted to $9^{\circ} \mathrm{O}$ with I $\mathrm{M}-\mathrm{NaOH}$. The solution was incubated for $\mathrm{I} 8 \mathrm{~h}$ at $37^{\circ} \mathrm{C}$ with $0.5 \mathrm{mg}$ alkaline phosphatase (Sigma) and then heated at $100{ }^{\circ} \mathrm{C}$ for $15 \mathrm{~min}$ to inactivate the enzyme. Glycerol in the hydrolysate was estimated by the method of Wieland (I965) in which glycerol is phosphorylated with glycerokinase in the presence of ATP, and the L-glycerol 3-phosphate thus formed is oxidized to dihydroxyacetone phosphate by $\alpha$-glycerophosphate dehydrogenase and NAD. Corrections were applied for extinction at $340 \mathrm{~nm}$ of reagents, and of a solution containing the hydrolysate, NAD and ATP but no enzymes. All enzymes and coenzymes were obtained from Boehringer.

Incubation with phosphatase. Samples ( $\mathrm{ml}$ ) were buffered to $\mathrm{pH} 9 \cdot 0$ with $\left(\mathrm{NH}_{4}\right)_{2} \mathrm{CO}_{3}$, incubated for $36 \mathrm{~h}$ with $0.5 \mathrm{mg}$ alkaline phosphatase and then neutralized with $\mathrm{HCl}$, and a portion was titred serologically by ring precipitin test.

Treatment with periodate. Samples ( $\mathrm{I} \mathrm{ml}$ ) were incubated with I $\mathrm{ml}$ of $\mathrm{I} \%$ (w/v) $\mathrm{NaIO}_{4}$ for $18 \mathrm{~h}$ at room temperature in the dark. Periodate was then removed by adding $0.03 \mathrm{ml}$ ethylene glycol, and a portion titred serologically by ring precipitin test.

Serological tests. Antisera to the membrane glycerol teichoic acid antigenic determinant common to Gram-positive bacteria were prepared using L. casei subsp. rhamnosus ATCC7469. Washed bacteria suspended in PBS were disrupted in a Braun homogenizer and, without any separation, stored in $\mathrm{I} \mathrm{ml}$ amounts at $-20^{\circ} \mathrm{C}$. One $\mathrm{ml}$ of this preparation was inoculated into rabbits intravenously or subcutaneously for a course of inoculations. Other rabbits were inoculated with whole heat-killed organisms (Sharpe et al. 1973). Antisera to B. fibrisolvens Nor 37 were prepared similarly. Antiserum to purified lipoteichoic acid obtained from L. casei subsp. rhamnosus ATCC7469 (antiserum 217) was kindly provided by Dr K. W. Knox. Other serological methods were those described by Sharpe et al. (1973).

Electron microscopy. To prepare sections, centrifuged bacteria were fixed for $\mathrm{I}$ h in $2.5 \%$ 
Table 2. Chemical analysis of teichoic acid from Butyrivibrio Nor 37

\begin{tabular}{lcc} 
& $\begin{array}{c}\text { Percentage } \\
(\mathrm{W} / \mathrm{W})\end{array}$ & $\begin{array}{c}\text { Molar ratio } \\
(\mathbf{P}=\mathrm{I})\end{array}$ \\
Phosphorus (P) & $9 \cdot \mathrm{I}$ & $\mathbf{I} \cdot 00$ \\
Glycerol & 27.6 & $\mathrm{I} \cdot 02$ \\
Hexose & $4 \cdot 0$ & 0.08 \\
Ester-linked amino acids & $0.0 \mathrm{I} 6^{*}$ & 0.05 \\
\multicolumn{1}{c}{$\mu \mathrm{mol} / \mathrm{mg}}$. &
\end{tabular}

Table 3. Serological precipitin reaction of three antisera tested against phenol extracts of different micro-organisms

The antisera tested were $\mathrm{Cr} 6 / \mathrm{B}, 2 \mathrm{I} 7$ and Nor 37 ; see text for details.

\section{Strain}

Lactobacillus casei ATCC 7469

L. acidophilus A22

Streptococcus bovis NCDO243

Streptococcus cremoris 924

Staphylococcus aureus $\mathrm{BB}$

Escherichia coli $\mathrm{NCTC} 8603$

E. coli $\mathrm{B}$

E. coli $\mathrm{H} 509 \mathrm{a}$

Salmonella typhimurium

Serratia marcescens

Pseudomonas sp.

Vibrio sp. ATCC47 I I

Bacteroides rumincola $\mathrm{B} \mathrm{I/} 8$

Bacteroides amylophilus 78

Butyrivibrio fibrisolvens 49, Nor 37 and IL6-3 I

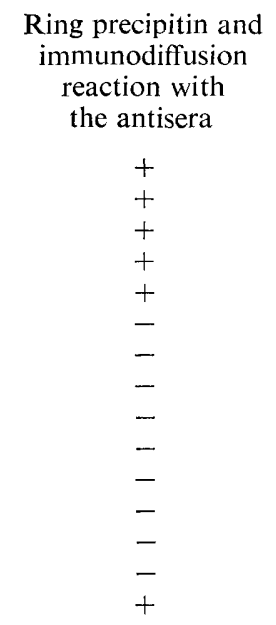

(w/v) glutaraldehyde in $0.2 \mathrm{M}$-cacodylate buffer $\mathrm{pH} 7 \cdot 2$ at room temperature. After several $\mathrm{I} \mathrm{h}$ washes in cacodylate- $\mathrm{HCl}$ buffer, $\mathrm{pH} 7 \cdot 4$, the bacteria were fixed in cacodylate-buffered $\mathrm{I} \%(\mathrm{w} / \mathrm{v})$ osmium tetroxide for $2 \mathrm{~h}$ and then transferred to $\mathrm{I} \%(\mathrm{w} / \mathrm{v})$ uranyl acetate in $25 \%(\mathrm{w} / \mathrm{v})$ ethanol for $\mathrm{I} \mathrm{h}$. Dehydration in a series of ethanol-water mixtures and absolute ethanol was followed by treatment with propylene oxide and propylene oxide-Araldite mixtures before embedding in Araldite. Thin sections were stained with uranyl acetate and lead citrate and examined in an Hitachi HU-I IE electron microscope.

\section{RESULTS}

\section{Paper chromatrography}

Because of the low yield of material in the final preparation from B. fibrisolvens Nor 37 , paper chromatography was carried out using the material from the Sepharose $4 \mathrm{~B}$ column. A sample $(2 \mathrm{mg}$ ) hydrolysed in $2 \mathrm{M}-\mathrm{HCl}$ contained glycerol, glycerol monophosphates and diphosphates, and inorganic phosphate as major components. All except glycerol diphosphate were identified by direct comparison with authentic samples. Only traces of material reacting with $\mathrm{AgNO}_{3}$ in alkali were detected, indicating that hexoses and pentoses were present only as minor contaminants. Alkaline hydrolysis gave glycerol monophosphate as the major product, plus some glycerol and glycerol diphosphate. Insufficient material was 

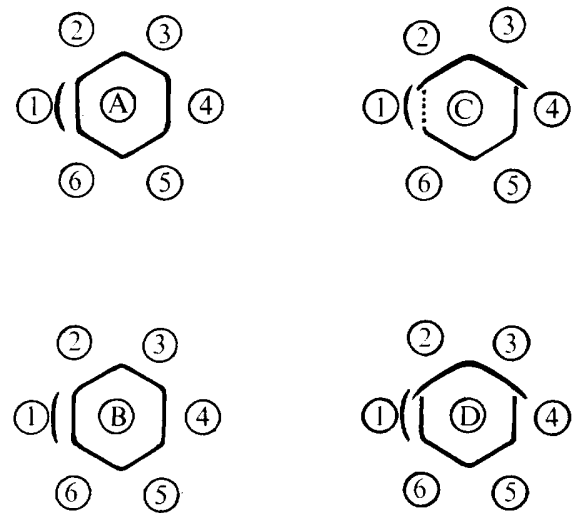

\begin{abstract}
Fig. I. Reactions between antisera to glycerol teichoic acid determinants and bacterial extracts. Centre wells: A, antiserum to purified lipoteichoic acid from Lactobacillus casei subsp. rhamnosus 7469 ; B and C, antisera to $L$. casei subsp. rhamnosus disrupted cells (C, after a long course of inoculations); D, antiserum to $B$. fibrisolvens disrupted cells. Outer wells: I. purified lipoteichoic acid isolated from $L$. fermentum; 2. membrane teichoic acid from $L$. casei Ro94; 3. phenol extract of Staphylococcus aureus Mexi; 4. phenol extract of Streptococcus bovis; 5 . phenol extract of $B$. fibrisolvens $49 ; 6$. teichoic acid from $B$. fibrisolvens Nor 37 .
\end{abstract}

available to allow detection and characterization of diglycerol triphosphate, which is a characteristic but minor alkaline hydrolysis product of $\mathrm{I} \rightarrow 3$-linked glycerol teichoic acids. These results are consistent with the presence of a non-glycosylated glycerol teichoic acid. A sample $(2 \mathrm{mg})$ hydrolysed in $6 \mathrm{M}-\mathrm{HCl}$ revealed several ninhydrin-positive components which were presumably amino acids derived from contaminating protein. One component had an $R_{F}$ similar to alanine, but this was not prominent.

\title{
Chemical analysis
}

The results of chemical analysis of the final product after TCA treatment are shown in Table 2. The molar ratio of glycerol to phosphorus is close to $\mathrm{I}: \mathrm{I}$, as would be expected in a glycerol teichoic acid. The low molar proportions of hexose and ester-linked amino acids indicate that the teichoic acid is largely non-glycosylated and also devoid of ester-linked alanine or other amino acids, and is in agreement with the results of paper chromatography. The chemical analysis does, however, indicate that some material remains unaccounted for in the analysis; some insoluble material was present even after hydrolysis in $2 \mathrm{M}-\mathrm{HCl}$ but the very low yield of material precluded any attempts at further purification.

\section{Serology}

Antisera. Of six rabbits inoculated with the disrupted organisms of $L$. casei subsp. rhamnosus ATCC7469, three produced antibodies reacting with the glycerol teichoic acid antigenic determinant; the other three, and the three rabbits inoculated with heat-treated cultures, produced antibodies only to the group C antigen of lactobacilli (Sharpe \& Wheater, I957) and/or to type antibodies. One of the three rabbits inoculated with disrupted organisms of B. fibrisolvens Nor 37 produced antibodies reacting weakly with the glycerol teichoic acid antigenic determinant (antiserum Nor 37). Harvests from the most potent antisera to $L$. casei subsp. rhamnosus reacting with the glycerol teichoic acid antigenic determinant were pooled and used as antiserum CI6/B. 
Table 4. Presence of glycerol teichoic acid (GTA) determinant in strains of butyrivibrios, as determined by ring precipitin and immunodiffusion reactions

\begin{tabular}{|c|c|c|}
\hline & \multicolumn{2}{|c|}{ Serological reaction showing GTA in strain } \\
\hline & Present* & Absent \\
\hline $\begin{array}{l}\text { B. fibrisolvens } \\
\text { Butyrivibrio spp. } \\
\text { Fresh isolates }\end{array}$ & $\begin{array}{l}49,7, \text { I } 2,15,17 \text {, Nor } 37, \text { IL6-3 I } \\
\text { JL, CE } 44 \\
22 \text { rumen strains, } 2 \text { caecum strains }\end{array}$ & $\begin{array}{l}\text { DI, A38, CI } 4,834 \\
\text { CE } 65, \text { CE } 66,6 \mathrm{~B}, 6 \mathrm{D}, 7 \mathrm{~A}, \mathrm{I} \mathrm{I} \\
9 \text { rumen strains }\end{array}$ \\
\hline
\end{tabular}

Ring precipitin and immunodiffusion tests. Table 3 shows the precipitin reactions of phenol extracts of strains from different bacterial species against antiserum Cr6/B. Only Grampositive and butyrivibrio strains showed a positive reaction. In addition, purified teichoic acid preparations of $L$. casei $\mathrm{RO} 94$ (I $5 \mu \mathrm{g} / \mathrm{ml})$, B. fibrisolvens Nor 37 (I $5 \mu \mathrm{g} / \mathrm{ml}$ ) and a lipoteichoic acid preparation of $L$. fermentum 699 I ( $15 \mu \mathrm{g} / \mathrm{ml}$ ) reacted strongly with undiluted antiserum CI6/B (titres 256, 256 and 128 , respectively) and also with antiserum to lipoteichoic acid (antiserum 217). Immunodiffusion tests with antisera CI6/B and 2I7 showed reactions of identity between the phenol extracts of all organisms giving a positive ring precipitin reaction and the three teichoic acid preparations. An extra precipitin line was observed with both antisera against the lipoteichoic acid preparation (Fig. I). An antiserum against $L$. casei subsp. rhamnosus 7469 from a rabbit inoculated over a long period, showed spurring of extracts of the three butyrivibrio strains with phenol extracts or with purified teichoic acid preparations of lactic acid bacteria. The antiserum to B. fibrisolvens Nor 37 also gave spurred reactions (Fig. I).

Quantitative precipitin tests. The amount of antibody in antiserum CI6/B reacting with the different teichoic acid preparations ranged from $3 \cdot 1$ to $4 \cdot 0 \mathrm{mg} / \mathrm{ml}$.

Absorption of antiserum $C_{1} 6 / B$. After removal of antibodies by absorption with $L$. case $i$ RO94 teichoic acid, or with $L$. fermentum 699I lipoteichoic acid, the antiserum no longer reacted with the Nor 37 teichoic acid, whilst removal of antibodies reacting with $B$. fibrisolvens Nor 37 abolished the reaction with $L$. casei R094 teichoic acid. However, when the antiserum was absorbed with either B. fibrisolvens NOR 37 or L. casei RO94, it still showed I5 \% activity on reaction with L. fermentum 6991 lipoteichoic acid. This was in agreement with the extra precipitin line seen with this preparation in the immunodiffusion test.

Inhibitory effect of $G_{3} P_{2}$ on precipitin reaction. The reaction between the $B$. fibrisolvens Nor 37 teichoic acid preparation $(2.5 \mu \mathrm{g})$ and antiserum $\mathrm{CI} 6 / \mathrm{B}(50 \mu \mathrm{l})$ was inhibited $60 \%$ by $23 \mu \mathrm{g} \mathrm{G}_{3} \mathrm{P}_{2}$.

Extracts of Nor 37 walls. Neither the phenol nor the TCA extract of the walls gave a positive ring precipitin reaction with antiserum CI6/B.

Treatment of phenol extract of strain Nor 37 with phosphatase and periodate. Treatment of a phenol extract with phosphatase or periodate did not reduce the precipitin titre. Treatment with phosphatase followed by periodate was also without effect.

Precipitin reactions of antiserum $C_{1} 6 / B$ with extracts of other butyrivibrios. Extracts of further strains of butyrivibrios were reacted serologically with antiserum to the glycerol teichoic acid determinant but this determinant could not be detected in all strains (Table 4). Using phenol and autoclaved bacterial extracts, positive ring precipitin reactions and immunodiffusion reactions of identity occurred with only nine of the laboratory strains and could not be detected in the other ten. None of the six strains belonging to group 2 of Shane et al. (I969) reacted, but with group I strains eight out of I 2 reacted. The borderline strain CE74 


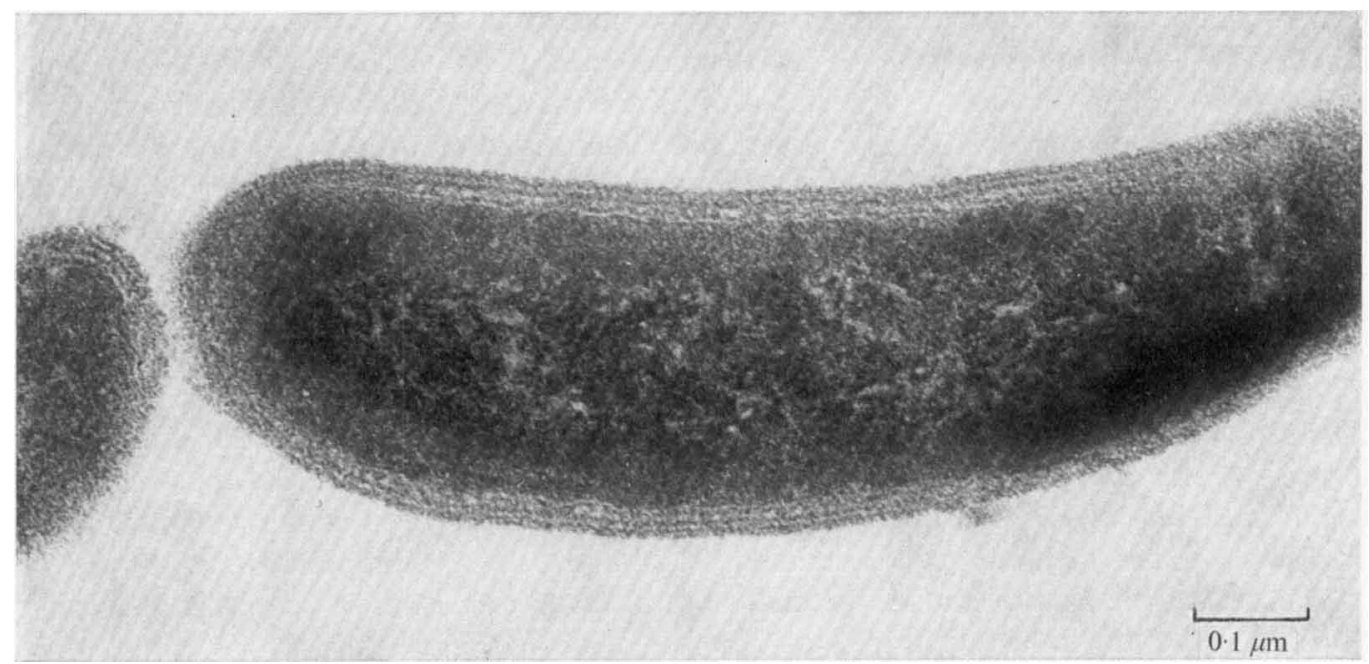

Fig. 2. Electron micrograph of sections of B. fibrisolvens Nor 37 .

was also positive. Extracts of 24 of the 33 fresh isolates $(72 \%)$ gave positive ring precipitin and immunodiffusion reactions but it was not determined if they were group I or group 2 . All 33 positive strains gave a reaction of identity with the glycerol teichoic acid prepared from Nor 37 .

\section{Electron microscopy}

An electron micrograph of sections of B. fibrisolvens Nor 37 (Fig. 2) indicates a multilayered wall which is atypical of classical Gram-positive or Gram-negative wall membrane profiles.

\section{DISCUSSION}

Butyrivibrios are among the most commonly occurring organisms in the rumen of cows on high roughage diets and their original description (Bryant \& Small, 1956) and all further work has consistently shown them to be Gram-negative.

The chemical analysis indicates that the serologically-active fraction isolated consists of glycerol and phosphate and is indicative of a glycerol teichoic acid. The serological results confirm the presence of such a teichoic acid determinant, antigenically similar to the polyglycerophosphate backbone of the membrane teichoic acids in Gram-positive organisms. These teichoic acids consist of I $\rightarrow$ 3-linked glycerol phosphate units (Baddiley, 1970) and the present findings are consistent with such a structure for the teichoic acid of $B$. fibrisolvens Nor 37. The fact that this antigenic determinant was not destroyed by periodate/phosphatase treatment indicates that the reaction could not have been due merely to a glycerophosphate end-group. This is supported by the lack of reaction between antiserum $\mathrm{C}$ I6/B and a phenol extract of Escherichia coli H509a (Table 2). This strain, possessing antigen O: I0O, has a terminal glycerophosphate group in the K antigen (Jann et al. 1970).

The immunodiffusion tests with one of the antisera prepared against $L$. casei subsp. rhamnosus 7469 using a very prolonged course of inoculations, and those with antiserum against $B$. fibrisolvens Nor 37 suggest that there may be slight differences in the structure of the glycerol teichoic acid antigenic determinant in the butyrivibrio and in the lactic acid bacteria.

This appears to be the first report of the isolation and chemical characterization of a 
glycerol teichoic acid from a Gram-negative organism. Clarke \& Lilly (1962) and Lilly, Clarke \& Meadow (1963) reported possible teichoic acid precursors in E. coli strain 26-26, and Lilly (I962) reported briefly the occurrence of ribitol and phosphate in the hydrolysate of a wall extract of the same organism. However, no teichoic acid was purified from this organism, and no quantitative chemical or serological analysis was made. Traces of glycerol were also reported to be present in hydrolysates of walls of $E$. coli в (Armstrong et al. 1959) but no further evidence for a teichoic acid in this strain has been presented, and we found that an extract of this organism did not react with antiserum CI6/B (Table 3). Recently, however, Argaman, Liu \& Robbins (1974) have shown that the capsular polysaccharide of Haemophilus influenzae type $\mathrm{b}$ contains a ribitol-phosphate component which gives rise to crossreactions with Gram-positive organisms containing ribitol teichoic acids in their walls. This is strongly suggestive of a teichoic acid-like structure in the capsule of this Gram-negative organism. Our Butyrivibrio, Nor 37, is of even greater interest, as in addition to a teichoic acid, it possesses the antigenic determinant of Salmonella O:4 (Sharpe \& Reiter, I972).

The method of isolation and the fact that glycerol teichoic acid was serologically undetectable in extracts of washed walls indicated that the teichoic acid was mainly associated with the intracellular fraction of disrupted organisms, the small amount of wall-associated material being easily removed by washing. Thus this teichoic acid appears to be analogous to the membrane-associated teichoic acid of Gram-positive bacteria rather than to a wall teichoic acid. The exact location of this teichoic acid would be of considerable interest. Subsequent investigations of products extractable by phenol from this strain indicate that it contains a substance with the chemical and serological properties of a lipoteichoic acid (A. J. Wicken, K. W. Knox and M. E. Sharpe, unpublished).

We thank Dr K. W. Knox for helpful discussions, Dr B. E. Brooker and Mr D. Hobbs for the electron microscopy and Mrs M. Crossfield for expert technical assistance.

\section{REFERENCES}

Argaman, M., Liu, T-Y. \& Robbins, J. B. (1974). Polyribitol-phosphate: an antigen of four Gram-positive bacteria cross-reactive with the capsular polysaccharide of Haemophilus influenzae type b. Journal of Immunology 112, 649-655.

Armstrong, J. J., Baddiley, J., Buchanan, J. G., Davison, A. L., Kelemen, M. V. \& Neuhaus, F. C. (1959). Composition of teichoic acids from a number of bacterial walls. Nature, London 184, 247-248.

Baddiley, J. (1970). Structure, biosynthesis and function of teichoic acids. Accounts of Chemical Research 3 , 98.

Bryant, M. \& Small, N. (1956). The anaerobic monotrichous butyric acid producing curved rod-shaped bacteria of the rumen. Journal of Bacteriology 72, I6-2 I.

Clarke, P. H. \& Lilly, M. D. (I962). A general structure for cell walls of Gram-negative bacteria. Nature, London I95, 5I6-I7.

VAN GylswyK, N. O. \& Roché, C. E. G. (I970). Characteristics of Ruminococcus and cellulolytic butyrivibrio species from the rumens of sheep fed differently supplemented teff (Eragrostis tef) hay diets. Journal of General Microbiology 64, 1 I-17.

Hungate, R. E. (1950). The anaerobic, mesophilic cellulolytic bacteria. Bacteriological Reviews 14, I-49.

JANN, B., JANN, K., SCHMIDT, G., ØRSKov, I. \& ØRSKov, F. (1970). Immunochemical studies of polysaccharide surface antigens of Escherichia coli OIO0:K?(B):H2. European Journal of Biochemistry I5, 29-39.

Leatherwood, J. M. \& Sharma, M. P. (1972). Novel anaerobic cellulolytic bacterium. Journal of Bacterio$\log y$ II0, $75 \mathrm{I}-753$.

LiLly, M. D. (1962). Cell wall precursors in Escherichia coli strain 26-26. Journal of General Microbiology 28, ii-iii.

Lilly, M. D., Clarke, P. H. \& Meadow, P. M. (1963). The accumulation of nucleotides by Escherichia coli strain 26-26. Journal of General Microbiology 32, $103-116$. 
Roché, C., Albertyn, H., van Gylswyk, N. O. \& Kistner, A. (I973). The growth response of cellulolytic acetate-utilizing and acetate-producing butyrivibrios to volatile fatty acids and other nutrients. Journal of General Microbiology 78, 253-260.

Shane, B. S., Gouws, L. \& Kistner, A. (1969). Cellulolytic bacteria occurring in the rumen of sheep conditioned to low-protein teff hay. Journal of General Microbiology 55, 445-457.

Sharpe, M. E., Brock, J. H., Knox, K. W. \& Wicken, A. J. (1973). Glycerol teichoic acid as a common antigenic factor in lactobacilli and some other Gram-positive organisms. Journal of General Microbiology 74, I I9-126.

Sharpe, M. E., Latham, M. J. \& Reiter, B. (1969). The occurrence of natural antibodies to rumen bacteria. Journal of General Microbiology 56, 353-364.

Sharpe, M. E. \& Reiter, B. (1972). Common antigenic determinant in a rumen organism and in Salmonellae containing the antigen $\mathrm{O} 4$. Applied Microbiology 24, 6I3-6I 7 .

Sharpe, M. E. \& WheATER, D. M. (1957). Lactobacillus helveticus. Journal of General Microbiology 16, $676-679$.

Wicken, A. J., Gibbens, J. W. \& Knox, K. W. (I973). Comparative studies on the isolation of membrane lipoteichoic acid from Lactobacillus fermentum. Journal of Bacteriology 113, 365-372.

Wieland, O. (1965). Glycerol. In Methods of Enzymatic Analysis, pp. 2 I I-214. Edited by H.-U. Bergmeyer. London: Academic Press.

Wilkinson, S. G. (1968). Glycosyl diglycerides from Pseudomonas rubescens. Biochimica et biophysica acta I64, I48-I 56. 